\title{
From Working-Class to Immigrant Areas? The Case of Two Former Industrial Districts
}

\section{Giacomo Solano}

University of Milano-Bicocca

giacomo.solano@gmail.com

\section{Doi:10.5901/ajis.2013.v2n8p127}

\section{Abstract}

In this paper I consider the situation of two former industrial districts of Genoa - Cornigliano and Sestri Ponente - in order to problematize the substitution mechanism between blue-collar (working class) and white-collar (middle class) workers. As underlined in the literature on post-Fordism, with the end of Fordism there was a general shift in the population composition, with a strong decrease of the working class and an increase of the middle class. At the same time, studies on immigration in various neighborhoods show that in some cases these former industrial areas have become target areas of immigration. In my research I show that the switch from working class to middle class happened completely only in those areas which were successful in their transition into a post-industrial configuration (Sestri Ponente in my research). On the contrary, in the areas where deindustrialization led to degradation and unemployment (Cornigliano in my study), the process was very different: there is a drastic increase of people from all over the world, and, although the middle class did in fact increase, working-class people were largely replaced by immigrants in these areas. It is important to underline that some areas became middle-class districts while others largely became areas of immigration. In this sense, it is possible to speak of a different substitution process. The (partially) unsuccessful industrial transformation and the negative consequences of having had an industrial past seem to lead to a general degradation of some areas, therefore attracting immigrants because of their economic difficulties, and essentially "pushing out" the middle-class population (typically the children of blue-collar workers). In conclusion, I analyze various transition paths leading from an industrial to a post-industrial situation, in order to underline a process which is not clearly shown in the literature, i.e. the substitution mechanism from working class, blue-collar workers to immigrants, in those areas where coming out of the industrial era was problematic.

Keywords: "Fordism", "Post-Fordism", "Immigration", "Middle class" "Working class"

\section{Introduction}

From the 70s, the crisis of Fordism led to different situations both in production ways and population composition. In particular, former industrial and basically working-class cities - as well as areas within cities - suffered many changes because of the transition to post-Fordism.

In the course of this transition, several transformations occurred, in which general lines of change can be identified (see par. 2). The literature on post-Fordism underlines that, with the end of Fordism, there was a general shift in population composition, with a strong decrease of the working class and an increase of the middle class. In this article, I partially question this process, both by considering immigrants and by focusing on the districts' levels.

The new economic structure has changed - and is still changing - the role of the city and that of the various areas within the city (Castells 1996; Sassen, 1994). According to Sassen (1994), the new economy creates a new geography of centrality and marginality (especially in cities, but also in particular areas within the same city), closely linked to their ability to change their productive structure and to adapt to the emerging situation.

Within cities, many formerly industrial areas experience some difficulties. The degradation of these areas generates certain problematic phenomena (material deprivation, family instability, degradation of housing, street crime) and perceptions related to squalor, e.g. the stigma of place, and the omnipresent climate of fear and anguish (Wacquant, 2008). Despite these difficulties, not all areas suffer these transformations passively, and some areas have managed to change. For this reason, there are numerous (different) ways of coming out of Fordism within the same city.

This paper derives from a study carried out in two former industrial areas located in the Western area of Genoa, i.e. Cornigliano and Sestri Ponente. In particular, I analyse the history of these two areas in order to show the different processes of substitution when going from a Fordist to a post-Fordist situation. 
From a methodological point of view, the research is based on interviews with key informants, on the analysis of the available statistical data (mainly from the Census ${ }^{1}$ ), on the historical and sociological literature.

In the first section I summarize the main processes connected with Fordism/post-Fordism and immigration in different neighbourhoods. In the second section I focus on the transformations and the current situation of the two areas (Cornigliano and Sestri Ponente), with particular reference to the population composition.

Finally, I discuss the results in order to highlight what the two case-studies suggest.

\section{Theoretical and empirical background}

\subsection{The transition to post-Fordism}

The term Post-Fordism refers to the overcoming of the Fordist economy due to the economic crises that hit the Western economies during the $70 \mathrm{~s}^{2}$. The crisis of Fordism originated both in its Taylorist characteristics and its regulative aspects (linked to the welfare state). The Taylorist principles lost some of their efficiency with the advent of technology and the internationalization of the economy, which made governmental control more difficult.

This crisis led to a phase of slower economic growth, rising inflation and unemployment.

Over the same period, the economy, which in the past had been centred on the production of goods, became based on services, with a tertiarization of the economic sphere. The enhanced development of services happened in certain fields in particular. With industrial development there was a general expansion of transportation and utilities, and with the advent of post-Fordism there was a rise in finance, real estate and insurance. In particular, personal services were greatly expanded: the general increase of this sector was also accompanied by a change within, in the sense that some service sectors (such as finance, real estate, insurance, healthcare, education, leisure and public administration) had a significant increase in size and in number of employees (see: Bell, 1973; Walker, 1985).

Focusing more on the issue that I am most interested in, it is important to underline the changes in the labour market and the class structure.

In this regard, there are two processes I wish to underline.

The first is a marked decrease of blue-collar workers and the growth of white-collar workers. A blue-collar worker is a worker performing manual labor whereas the term white-collar worker refers to a person doing an administrative, professional or managerial job. With the shift to a more service-based economy, there was a reduction in the number of workers employed in the secondary sector and an increase of those in the service sector (tertiary sector).

The class of professional and technical workers (e.g.: teachers, health workers, technicians, engineers), i.e. the socalled "white collars", thus became predominant, and the working class lost its privileged role as a historical actor - so much so that André Gorz (1980) entitled one of his books Adieux au Proletariat.

However, this process had already started in the industrial era, as highlighted in the 1950s by C. Wright Mills' famous book White Collar. He noted that, in the period from 1870 to 1940, the middle class was the only stratum of society which was constantly increasing, although it still hadn't become the majority. But the key aspect of post-Fordism is the "reversal of the tendency towards deskilling and worker isolation, through greater reliance on skills, polyvalence, worker participation and collaboration in the pursuit of product quality and the flow of ideas, know-how and workers between task and product areas" (Amin, 1994, p. 21).

The second process concerns the educational level. The transition to post-Fordism was characterized by mass education, which also involved the most vulnerable and marginalized people. There was a marked process of rising educational levels and an increase of required skills for getting a job.

These two processes led to a revolution in the class structure, with a further increase of the middle class, who became dominant. This is what Wacquant (2004) calls de-proletarianization. The transition from Fordism to post-Fordism caused a change in general class composition; in many formerly industrial areas there was a process of substitution from blue-collar workers (working class) to white collar ones (middle class).

\footnotetext{
1 Unfortunately most of the data is taken from the 2001 Census because the results of the 2011 Census are not yet available.

${ }^{2}$ For an overview of the main characteristics of the transition to post-Fordism, see for example: Bell, 1973. 


\subsection{Immigration in formerly industrial areas}

In parallel with the literature on Fordism and post-Fordism, some authors analysing the development of immigration in city neighborhoods show that many former industrial areas host a high percentage of immigrants (e.g. Schmitter Heller, 1994; Agustoni \& Alietti, 2009).

Especially - but not only - for economic reasons, immigrants usually tend to settle in areas where environmental and housing quality is low (Musterd, 2005). In this regard, it is not possible to talk about ghettos in Europe, as in the American context (Wacquant, 2004), but rather of "neighborhoods of migration" (Cologna, 2002).

Immigrant families usually settle in areas which have already been left by the local population because of social and environmental decline. This is because natives with greater resources decide to move to areas better suited to their expectations. Consequently, there is a concentration process of immigrants and poorer natives in these neighborhoods.

This process has been studied and illustrated by studies in France (Lagrange \& Oberti, 2006) and Germany (Bürkner, 2002). The French case confirms that in neighborhoods where there has been a decrease of the working class (but also of the middle class), there has also been a gradual concentration of immigrants. The same process has occurred in Germany since the end of the 70 s, as a consequence of the industrial crisis.

Similarly, in Brussels (see: Kesteloot \& Cortie, 1998), many immigrants with economic difficulties, and also due to the unavailability of public housing, were "forced" to settle in areas that were already inhabited by immigrants or, previously, by the native working class.

With regard to Italy, Austoni and Alietti (2009) analyzed some neighborhoods in Milan. Without addressing the specific cases, what emerged from their study is that former industrial districts -which on the one hand are characterized by a marked industrialization between the 1800 s and the 1900 s and on the other hand are affected by deindustrialization linked to the post-Fordist transition of the city since the 1970s - are characterized by major degradation and numerous urban voids. In this scenario, these areas became the subject of migration flows, while preserving the characteristics of their previous industrial situation, i.e. large numbers of unskilled workers and a general low educational level.

In general, this process had already been pointed out by a pioneering study by Rex (1968). He underlined the fact that the relatively low rents attracted immigrants to "twilight zones", that is, urban spaces that were still waiting for a new re-definition within the wider context of city changes.

Analyzing the past literature (on Fordism/post-Fordism and on immigration in the districts) I have just shown that, on the one hand there was an increase of the middle class, and on the other hand, some former industrial areas became the destinations of immigrant fluxes. Although these two processes are not mutually exclusive, it seems that they are not complementary at district level. It is rare to see large numbers of immigrants in a middle-class neighborhood, in part due to the cost of housing. At the same time, white-collar workers rarely settle in areas with a large presence of migrants. Starting from these considerations, I try to combine the analysis of the two processes mentioned above in order to connect these two fields of research ("immigration and neighborhoods" and "Fordism and post-Fordism").

To do this, and in order to underline the (partially) different processes that took place, in the next paragraphs I am going to describe the cases of two closed areas of Genoa (Cornigliano and Sestri Ponente) which had a strong industrial vocation in the past. Genoa was one of the first cities affected by the process of deindustrialization (Manzitti \& Minella, 2001), and it is a paradigmatic example of a difficult transition to a post-Fordist economy. Moreover, in the city there are areas with different traditions, characteristics and history (Gazzola, 2003). For these reasons Genoa and its neighbourhoods are very interesting for the object of this study.

\section{The cases of Cornigliano and Sestri Ponente: industrial decline and current situation}

\subsection{History and transition to post-Fordism}

I now analyze the case of two former circoscrizioni3 located in the western area of Genoa. These two cases are emblematic both for their similarities and their differences. They also represent a kind of paradigmatic experiences of two different situations of "exit" from Fordism. The first was more successful (Sestri Ponente), the other less so (Cornigliano).

\footnotetext{
3 A circoscrizione was the smallest administrative unit of the Municipality of Genoa. In 2007 the 25 circoscrizioni in which Genoa was divided were replaced by 9 Municipi. With this operation the districts of Sestri Ponente and Cornigliano were united to form the Municipio Medio Ponente.
} 
Throughout this section I outline the history of the two areas, providing information on the current situation, in order to highlight the fact that the results of the transition to post-Fordism have been partially different.

First of all, it seems useful to quickly summarize the history of the two quarters. The districts of Sestri Ponente and Cornigliano are in the western part of the city, which was characterized by a strong industrial orientation. Although the two areas developed very similarly, they maintained two separate - although not so different - identities. With deindustrialization and the transition to post-Fordism, the two neighborhoods became more different, mainly because of the diverse relationship with their previous industrial development.

The modern steel and shipbuilding industries developed in Sestri as well as in Cornigliano in the last two decades of the 1800s. This industrialization did not develop without tensions and conflicts. Despite undeniable economic benefits in terms of jobs, this industrial growth produced an environmental degradation of the two areas, in particular in Cornigliano. In this area an emblematic sign of this decline was Raggio Castle. The castle, which was built at the end of the $1^{\text {th }}$ century by the entrepreneur and politician Edilio Raggio, was demolished in 1951 to make space for the Italsider, the most important steel factory of Cornigliano.

Analyzing the differences between Sestri Ponente and Cornigliano, their industrial development had an important dissimilarity with regard to the type of companies (Cevini, 2001). In Sestri the shipbuilding sector was predominant. There were also some manufacturing industries (such as Manifattura Tabacchi), but shipyards were much more numerous (e.g. Ansaldo, Odero, Cadenaccio). On the contrary, metallurgical industries - especially steel industries - dominated in Cornigliano (e.g. Italsider).

These types of production had significantly different effects on the two areas. The predominance of steel factories caused a worsening of environmental conditions, and Cornigliano was the area suffering more negative effects. In particular, there is a close connection between Italsider and Cornigliano. Since World War II and up to today, the history of this area has been characterized by this obtrusive presence, which has always had very negative effects on the neighborhood, blocking its post-industrial transformation and contributing to the image of degradation and pollution that the area currently evokes. On the contrary, the industries of Sestri Ponente were less invasive and they have had less environmental impact (Manzitti \& Minella, 2001).

From the '70s, the two areas gradually lost their industrial weight. This process created many problems in Cornigliano, but Sestri was also deeply affected by the changes.

The two areas responded differently, however. Cornigliano had - and still has - difficulty emerging from the old production model:

The real problem in Cornigliano is that there was a mono-culture, the steel industry, which had a great presence. In the past, this presence generated jobs; there was a time when twelve thousand people were employed, but now it has left only pollution. The problems are mainly in the part of Cornigliano near the sea, where Italsider was located. It is where environmental degradation is creating the most difficult social situations. (L. T.)

On the contrary, Sestri managed to recover more quickly, as is evident from the process of dismantling industrial activities.

In the deindustrialization process, Cornigliano failed to change its type of production and so it suffered more from the Fordist crisis. The problem was mainly that Italsider continued to operate at full capacity during the '90s. Only in 2005 was the blast furnace closed.

On the contrary, the process of deindustrialization happened sooner in Sestri Ponente (Manzitti \& Minella, 2001). The Sestri industries were closed earlier and this certainly facilitated the process of change in that area.

In Sestri, industries managed to change, encouraging technological innovation and labor specialization, which then led to an increased middle class (see par. 3.2). The change was from a strong presence of blue-collar workers to an almost exclusive presence of technicians and other white-collar employees. In particular, there was a growth of high-tech industries (e.g. San Giorgio, Elsag, Ansaldo and Marconi) that were already present in the area of Sestri Ponente:

Sestri shifted from a strong presence of manufacturing and blue-collar workers to an almost exclusive presence of technicians and other white collar employees. Moreover there was an evolution of the already present high-tech industry, with San Giorgio generating all the others. Now, the only strong Fordist presence is Fincantieri. (S. B.)

The fact that industries in Sestri have managed to change and adapt to the new economy has brought benefits to the entire area.

\subsection{Changes in population composition}

Regarding the population composition, it is interesting to focus on educational levels and employment. First of all, I will 
analyze the variables related to employment.

Sestri and Cornigliano were both working-class districts. According to the 1971 census, $56.3 \%$ of the people employed in Sestri worked in factories, and in Cornigliano the percentage was 57.5\%. During the same period, workers in the industrial sector in Genoa amounted to $38.1 \%$. Currently only $29 \%$ of the people in Sestri and $31 \%$ of those in Cornigliano work in the industrial sector.

Tab. 1. Workers in the industrial sector (\%)

\begin{tabular}{ccc}
\hline Year & Cornigliano & Sestri Ponente \\
1971 & 57.5 & 56.3 \\
2001 & 31.1 & 29.1 \\
$2001-1971$ & -26.5 & -27.3 \\
\hline
\end{tabular}

Source: Istat

These data reveal and confirm the deindustrialization that took place from the 1970s. The process of deindustrialization happened both in Sestri Ponente and in Cornigliano. If we compare the relative weight of this sector in 2001 with that of 1971, the decrease was $27.3 \%$ in Sestri and $26.5 \%$ in Cornigliano, whereas in the whole of Genoa the overall decline was $15.3 \%$.

The differences in the percentage of tertiary sector workers also confirm the deindustrialization process. From 1971 to 2001, the increase was very high: 26.8\% (from 43\% in 1971 to $70.1 \%$ in 2001) in Sestri and 26\% (from 41.6\% to $67.6 \%$ of total employees) in Cornigliano. These numbers show that the two areas underwent a general shift to the tertiary sector, but that in Cornigliano this change was less evident, especially considering that there were fewer tertiary sector workers in the first place compared to Sestri.

Tab.2. Workers in the tertiary sector (\%)

\begin{tabular}{ccc}
\hline Year & Cornigliano & Sestri Ponente \\
1971 & 41.6 & 43.3 \\
2001 & 67.6 & 70.1 \\
$2001-1971$ & +26 & +26.8 \\
\hline
\end{tabular}

Source: Istat

If we analyze the number of blue-collar workers in the two areas, we see that in 1971, these were fewer in Sestri (59.9\%) than in Cornigliano (68.9\%), whereas in $1991^{4}$ there were $42.1 \%$ in Sestri and 56.9\% in Cornigliano. This clearly indicates that Sestri is coming out of a "proletarian" dynamic that characterized it up until the 1980s, although the percentage of blue-collar workers remains higher than in the historically middle-class districts of the city 5 .

Moreover, it is important to underline the fact that most of those blue-collars workers in Sestri are "qualified" ones ${ }^{6}$ (Longoni, 2010). In Cornigliano the process of qualification of workers has not yet been completed.

An analysis of the percentage of entrepreneurs and professionals confirms a general higher job qualification for residents of Sestri Ponente (4.55\% compared to $2.29 \%$ in Cornigliano).

Tab.3. Blue-collar workers on total workers (\%)

\begin{tabular}{ccc}
\hline Year & Cornigliano & Sestri Ponente \\
1971 & 68.9 & 59.9 \\
1991 & 56.9 & 42.1 \\
$1991-1971$ & -12 & -17.8 \\
\hline
\end{tabular}

Source: Istat

The fact that one of the two districts has become more of a middle-class area while the other hasn't is also shown by the

\footnotetext{
${ }^{4}$ The 1991 data was the latest to be analyzed because in 2001 the distinction between "managers, supervisors, executives", "office workers", and "laborers" disappeared.

${ }^{5}$ For example in Pegli, a residential area of West Genoa (near Sestri Ponente), the percentage of blue-collar workers was $27.3 \%$ in 1991

${ }^{6}$ By qualification I mean the transition from simple laborer to skilled worker.
} 
changes in the number of university and high school graduates. In 1971 the percentage of university graduates was $0.9 \%$ in Sestri and $0.7 \%$ in Cornigliano, and in 2001 these had grown to 5.9\% and 3.5\% respectively. As for the percentage of high school graduates, it had gone up to $6.7 \%$ and $4.8 \%$ respectively. Now, it is $27.2 \%$ in Sestri Ponente and $20.6 \%$ in Cornigliano.

If the two are added together, the difference precisely delineates a clear division between the two areas. In Sestri Ponente, $33.2 \%$ of the population has a medium-high level of education, while the percentage is only $24.1 \%$ in Cornigliano.

From 1971 to 2001, the increase was 25.5\% in Sestri, and 18.5\% in Cornigliano, making it clear that the general upward trend was lower in Cornigliano than in Sestri Ponente.

Tab. 4. People with a middle-to-high level of education (\%)

\begin{tabular}{cccc}
\hline Year & Degree & Cornigliano & Sestri Ponente \\
& High school & 4.8 & 6.7 \\
\multirow{2}{*}{2071} & University & 0.7 & 0.9 \\
& Total & 5.5 & 7.6 \\
& High school & 20.6 & 27.2 \\
& University & 3.5 & 5.9 \\
& Total & 24.1 & 33.2 \\
& High school & +15.7 & +20.5 \\
$2001-1971$ & University & +2.8 & +5 \\
& Total & +18.5 & +25.5 \\
\hline
\end{tabular}

Source: Istat

Another important point concerns immigrants. With regard to this point there are some differences. In Cornigliano arrivals from other countries have been massive, while in Sestri this phenomenon has been less extensive. Currently the share of the foreign-born population is increasing very fast in Cornigliano. The percentage of immigrants has gone up from $5.8 \%$ in 2001 to $18.6 \%$ today. There has been an increase of $12.8 \%$ in the last ten years. Although to a lesser degree, Sestri is also experiencing an increase of its immigrant population. Since 2000 the share of the foreign resident population has increased from $2.9 \%$ to $7.2 \%(+4.3 \%)$. This percentage of immigrants is in line with the Italian percentage (7.5\%) but below the city average (9.7\%).

Tab. 5. Percentage of foreign-born residents

\begin{tabular}{ccc}
\hline Year & Cornigliano & Sestri Ponente \\
1981 & 2.2 & 1.8 \\
1991 & 2.7 & 2.5 \\
2001 & 5.8 & 2.9 \\
2011 & 18.6 & 7.2 \\
\hline
\end{tabular}

Source: Istat

The data shows that Cornigliano is becoming a pole of attraction for immigrants, i.e. a district of immigration (Cologna, 2002). The area was also a point of arrival for immigrants in the past, but mainly for people from other parts of Italy. However, compared to the past, there is now a major difference in the reasons for settling in Cornigliano: in the past the main motivation was to work in the local factories and to live near the "big factory", whereas nowadays immigrants settle in the area mainly because of the lower housing prices.

\subsection{Discussion}

The examples of Cornigliano and Sestri Ponente show that the transition processes to post-Fordism can have various outcomes in different areas within the same city. This seems to be linked to differences in industrial impact and to later industrial dismantling (see par. 3.1).

The two areas, which were once industrial zones par excellence, are currently going through different situations and, in some ways appear to be heading in opposite directions. They both experienced a substantial drop in the 
importance of industry, but they have taken different post-industrial paths. Sestri Ponente managed to change by becoming a middle class residential area. On the contrary, Cornigliano still seems too tied to its industrial past, particularly because its environment is compromised. The price of housing reflects these different situations: the value of properties is lower in Cornigliano than in Sestri Ponente. According to data provided by the Agency of the Territory ${ }^{7}$ these values are $2875\left(€ / \mathrm{m}^{2}\right)$ for Sestri Ponente compared to $1932\left(€ / \mathrm{m}^{2}\right)$ for Cornigliano.

Sestri Ponente was able to "ride" the crisis because local industries evolved by pushing technological innovations. The area managed to change its economic and production structure so as to fit into the new post-Fordist "status".

On the contrary, Cornigliano had, and still has, great difficulty in re-qualifying the gaps left from former factories. It still seems too closely tied to its industrial past, and it is in trouble both in environmental (degradation, pollution) and social terms. Cornigliano hasn't completed the transition, except for the fact that local factories declined without being replaced with other productive activities, and this has had negative consequences on the territory.

In this scenario, many middle-class natives decided to move to other, better parts of the city. In Cornigliano the poorer native population remained, and at the same time more and more foreigners arrived. In other words, where Sestri illustrates the classic mechanism of substitution from traditional working class to new middle class, in Cornigliano the situation is the opposite: although the middle class has increased, the working-class has largely been replaced by immigrants. The first has become a middle-class area, and the other is now a district of migration. It is in these terms - at the district level - that we can speak of different substitution processes.

There is a connection between the areas' transformations and the fact that the substitution process has turned into an increase in the number of immigrants.

The results suggest that the substitution process (working class to middle class) happened mainly in the areas that were successful in their transition into a post-industrial configuration (Sestri Ponente in this research study). On the contrary, in the districts where deindustrialization led to a situation of degradation and unemployment (Cornigliano in this case), the working class population was largely replaced by immigrants.

This fact seems to be closely connected to certain reasons.

Firstly, the continued presence of some "Fordist" factories attracts immigrants. Workers' children, who are better educated and not willing to follow into their fathers footsteps, do not go on to replace them in the factories. Thus, immigrants settle in the area because they are attracted by the jobs offered by the "surviving" factories.

Secondly, a degraded urban environment leads to the fact that the middle-class population (e.g. the blue-collar workers' children), with profitable and more prestigious jobs, decide to move to more beautiful parts of the city. Concurrently, migrants - who usually constitute the poorer part of the resident population - decide to settle in these problematic areas, mostly because of the lower cost of living (house prices and rent).

\section{Conclusions}

In summary, with deindustrialization, one area, Sestri Ponente, was able to become a middle-class district. On the contrary, Cornigliano faces many difficulties (pollution, social degradation, etc.) because of its difficult exit from Fordism.

My analysis suggests that the substitution from working class to middle class happened mainly in those areas that were successful in their transition into a post-industrial situation, and that in the areas experiencing difficulties in renewing themselves, the former working-class was largely replaced by immigrants.

Hence, there is a different process of substitution: Sestri Ponente has become a middle-class district and Cornigliano is now a district of migration. It is at a district level that it is possible to underline different processes of substitution.

Considering the causes of these different processes, the (partially) unsuccessful industrial transformation and the bad consequences of their industrial past seem to lead to a general degradation of some areas, both by attracting immigrants (because they often have economic difficulties) and by "pushing out" the middle-class population (typically the children of former blue-collar workers). Therefore, the more extensive environmental degradation led to lowering the "level" of the district, which led many middle-class people to move out to other, more desirable neighborhoods, and they in turn were replaced by immigrants.

In conclusion, in this article I have shown the different paths of transition from Fordism to post-Fordism. In particular I have tried to connect the literature on Fordism/post-Fordism with that on immigration fluxes in the

\footnotetext{
${ }^{7}$ Year of reference: 2012.
} 
neighborhoods.

On the one hand, the literature on post-Fordism underlines the general mechanism of substitution between bluecollar (working class) and white-collars workers (middle class). On the other hand, studies on immigration in these districts show that in some cases these formerly industrial areas now have a large presence of immigrants.

My study on two areas of Genoa has tried to provide a first explanation of these two different views, with a small "contribution" to explain the fact that some former industrial areas have become districts of immigration (see: Cologna, 2002; Agustoni, Alietti, 2009). Moreover, I have attempted to hypothesize some reasons (see par. 3.3) for these different transition paths, and in particular for the switch from a working class to an immigrant area. Finally, only by analyzing these phenomena at the district level is it possible to explain why the findings from both branches of the literature show different processes which.

\section{References}

Agustoni, A. \& Alietti, A. (Ed.). (2009). Società urbane e convivenza interetnica. Vita quotidiana e rappresentazioni degli immigrati in un quartiere di Milano. Milano: Franco Angeli.

Amin, A. (Ed.). (1994). Post-Fordism. A Reader. Oxford: Blackwell.

Baggiani, B., Longoni, L. \& Solano, G. (Ed.). (2011). Noi e l'altro? Materiali per l'analisi e la comprensione dei fenomeni migratori contemporanei. Bagnacavallo (Ra): Discanti.

Bell, D. (1973). The Coming of Post-Industrial Society. New York: Basic Books.

Bürkner, H-J. (2002). Housing Policy and the Formation of Cultural Boundaries. Migration, 39-40-41, 91-111.

Carlini, G. (2005). Costruzione e ricostruzione di identità nei quartieri genovesi. In Petrillo, A. Identità urbane in trasformazione (pp. 105117). Genova: Coedit.

Castells, M. (1996). The Rise of the Network Society. Oxford: Blackwell.

Cevini P. (2001). Sviluppo urbanistico ed industriale dell'area. In AA. VV. Urban Genova: rinascere in Europa. Un progetto della Comunità Europea per Cornigliano e Sestri Ponente (pp. 11-16).

Cologna, D. (Ed). (2002). La Cina sotto casa. Milano: Franco Angeli.

Esping-Andersen, G. (1999). Social Foundations of Postindustrial Economies. Oxford: Oxford University Press.

Gazzola, A. (2003). Trasformazioni urbane. Società e spazi a Genova. Napoli: Liguori Editore.

Gorz, A. (1980). Adieux au proletariat. Paris: Editions Galilée.

Kesteloot, C. \& Cortie, C. (1998). Housing Turks and Moroccans in Brussels and Amsterdam: the difference between private and public markets. Urban Studies, 35(10), 1835-1853.

Kumar, K. (1978). Prophecy and Progress. The Sociology of Industrial and Post-Industrial Society. Harmondsworth: Penguin Books.

Lagrange, H. \& Oberti, M. (Ed). (2006). Émeutes urbaines et protestations: une singularité française. Paris: Les presses de Sciences Po. Longoni L. (2010). Quartieri sconfinati. II quartiere nella città contemporanea: un'unità complessa di analisi. Genova: Ecig.

Longoni, L., Solano, G. \& Baggiani, B. (Ed). (2012). La città nell'epoca della globalizzazione. Roma: Aracne Editrice.

Manzitti, F. \& Minella, M. (Ed). (2001). Ripartire da Genova. Gli anni che hanno cambiato il volto di una città industriale 1985-2001. Genova: Sagep.

Mills, C.W. (1951). White Collar. The American Middle Class. New York: Oxford University Press.

Musterd, S. (2005). Social and ethnic segregation in Europe. Levels, causes, effects. Journal of Urban Affairs, 27(3), 331-348.

Piore, M.J. \& Sabel, C. (1984). The Second Industrial Divide: Possibilities for Prosperity. New York: Basic Books.

Rex, J. (1968). The sociology of the Zone in transition. In E. Pahl. Readings in Urban Sociology (pp. 211-232). London: Permagamon Press,.

Sassen, S. (1994). Cities in a World Economy, Thousand Oaks: Pine Forge.

Schmitter Heller, B. (1994). Housing Policy and the Underclass: the United Kingdom, Germany, and the Netherlands. Journal of Urban Affairs, 16(3).

Solano G. (2012). I cambiamenti dello spazio sociale: globalizzazione, stato e città. In Longoni, L., Solano, G. \& Baggiani, B. (Ed). (2012). La città nell'epoca della globalizzazione (pp. 15-45). Roma: Aracne Editrice.

Tagliatti, L. (2003). Campi di fabbrica. 150 di industria pesante a Cornigliano.

Wacquant, L. (2004), Ghetto. In Smelser N.J. \& Baltes P.B. (Ed), International Encyclopedia of Social and Behavioral Sciences (pp. 129-147). London: Pergamon Press.

Wacquant, L. (2008). Urban Outcasts, Cambridge: Polity Press.

Wacquant, L. \& Wilson, J.W. (1989). The cost of racial and class exclusion in the inner city. Annals of the American Academy of Political and Social Science, 501, 8-25.

Walker, R.A. (1985). Is there a Service Economy?. Science and Society, 49(1), 42-83. 